\title{
Targeted Enzyme Therapy of Experimental Glomerulonephritis in Rats
}

\author{
Richard B. White, ${ }^{\star}$ Lia Lowrie, ${ }^{\ddagger}$ John E. Stork, ${ }^{\ddagger}$ Samy S. Iskandar, ${ }^{3}$ Michael E. Lamm, ${ }^{\star}$ and Steven N. Emancipator \\ Institute of Pathology ${ }^{*}$ and Department of Pediatrics, ${ }^{\ddagger}$ Case Western Reserve University School of Medicine \\ and University Hospitals of Cleveland, Cleveland, Ohio 44106; and Department of Pathology, \\ Bowman Gray School of Medicine, Winston-Salem, North Carolina 27103
}

\begin{abstract}
We sought to determine whether systemic administration of proteases ameliorates membranous nephritis induced in rats by immunization and challenge with cationic bovine gamma globulin, and whether targeting of protease to glomerular capillaries increases efficacy. Proteases substituted with biotin were targeted via the cationic protein avidin $A$, which by virtue of its charge has affinity for the glomerular basement membrane. Despite identical pretreatment proteinuria, rats given untargeted protease (biotin-conjugated without avidin, or unconjugated plus avidin) had significantly less proteinuria than salinetreated controls and nephrotic rats given avidin plus biotin-conjugated (targeted) protease had even less proteinuria and reduced glomerular rat IgG and C3. Among more severely nephrotic rats, targeted protease was again more effective than untargeted protease at reducing proteinuria, and also decreased the size of electron-dense glomerular deposits, hypercholesterolemia, and creatininemia. Inactivated targeted proteases had no effect on proteinuria, hypercholesterolemia, or azotemia. Finally, active targeted protease did not affect proteinuria in the nonimmune mediated nephrosis induced by puromycin aminonucleoside. We conclude that systemic protease can specifcally diminish glomerular immune deposits, proteinuria, hyperlipidemia, and creatininemia associated with experimental immune complex glomerulonephritis but not toxic nephrosis, and that targeted protease is more effective than untargeted protease. (J. Clin. Invest. 1991.87:1819-1827.) Key words: avidin - basement membrane $\bullet$ biotin • endopeptide $\bullet$ glomerulonephritis • hydrolases
\end{abstract}

\section{Introduction}

Immune complex glomerulonephritis is often a chronic progressive disease in which multiple, interrelated mechanisms appear to underlie altered glomerular function and glomerulosclerosis (1). To the extent that multiple inflammatory pathways lead to the same outcome, the most efficient pharmacologic intervention would be directed to mediators common to the different pathways. On the other hand, attenuation of the glo-

This work was presented in preliminary form at the 20th Annual Meeting of the American Society of Nephrology, December 1987, in Washington, DC.

Address reprint requests to Dr. Emancipator, Institute of Pathology, 2085 Adelbert Road, Cleveland, OH 44106.

Received for publication 30 May 1989 and in revised form 19 November 1990.

J. Clin. Invest.

(c) The American Society for Clinical Investigation, Inc. $0021-9738 / 91 / 05 / 1819 / 09 \$ 2.00$

Volume 87, May 1991, 1819-1827 merular immune deposits themselves would offer a therapeutic modality common to a variety of glomerulonephritides. Indeed, the most widely applied treatments operate by virtue of immunosuppressive effects (2-7) or removing immunoglobulin aggregates from the circulation $(8,9)$. In selected experimental systems where the antigen is known, the hazards of general immunosuppression and/or plasmapheresis have been avoided by dissolving immune deposits from glomeruli through systemic administration of large excesses of the very antigen which evoked formation of the immune complexes (10-12). A similar approach, assuming that rheumatoid factor is an important nephritogenic antibody in human lupus nephritis, has used high doses of human $\gamma$-globulin to ameliorate glomerular dysfunction in patients with this disease (13).

We $(14,15)$ and others $(16)$ independently reasoned that dissolution of deposited immune complexes might be achieved without knowledge of the culprit antigen by enzymatic cleavage of the immune lattice. Proteases administered intraperitoneally, intravenously, and orally to mice, rats, and rabbits significantly reduced the glomerular immune deposits associated with passive serum sickness $(14,16)$ and the heterologous and autologous phases of passive Heymann nephritis (15) at doses devoid of overt toxicity. Proteases also decreased the proteinuria of passive Heymann nephritis (15).

In the present work, we sought to determine whether protease therapy is effective on the glomerular immune deposits of active serum sickness nephritis and whether such treatment would abate the elements of the attendant nephrotic syndrome. Active serum sickness was induced in rats with cationic bovine $\gamma$-globulin (cBGG) ${ }^{1}$ (17). In this model the cationic nature of the antigen promotes glomerular capillary wall deposition of antigen and antigen/antibody complexes by binding electrostatically to the polyanionic heparan sulfate indigenous to the capillary basement membrane (18). We also hypothesized that cationic avidin could target biotinylated proteolytic enzymes to localize in the same distribution as cationic immune complexes, thereby improving the efficacy of the enzymes in removing glomerular immune deposits. To test the hypothesis we exploited the high binding affinity of the naturally cationic protein avidin A for biotin to target biotinyl proteases to sites where cationic proteins lodge.

\section{Methods}

Pilot studies on feasibility of targeting. 18 male 200-g Sprague-Dawley rats (Zivic-Miller Farms, Austin Park, PA) received $1 \mathrm{mg}$ of avidin A (Sigma Chemical Co., St. Louis, MO) in $0.5 \mathrm{ml}$ of saline i.v., and another six rats were given saline alone. An additional six rats were un-

1. Abbreviations used in this paper: $\mathrm{b}$, biotinylated; $\mathrm{cBGG}$, cationic bovine $\gamma$-globulin; EU, enzyme units; n, native; PAH, p-aminohippurate; SSA, sulfosalicylic acid. 
manipulated. After $30 \mathrm{~min}, 3.3 \mathrm{mg}$ of horseradish peroxidase Type VI (Sigma Chemical Co.), biotinylated (b-) exactly as with the proteases (see below), was injected i.p. into six rats given avidin i.v. and into the six rats given saline; another six rats given avidin received native (n-) peroxidase with the same activity $(1,000 \mathrm{IU}$ per rat $\sim 15,000$ millienzyme units [mEU] per rat), and the remaining six rats given avidin received saline i.p. After an additional $2 \mathrm{~h}$, rats were killed by exsanguination under ether anesthesia. Small fragments of renal cortex were snap frozen in 2-methyl-butane immersed in liquid nitrogen. Cryostat sections of kidney were washed in $0.15 \mathrm{M} \mathrm{NaCl}, 0.01 \mathrm{M}$ sodium phosphate, $\mathrm{pH} 7.4$ (PBS), and incubated in $0.075 \%$ 3,3' diaminobenzidine (Sigma Chemical Co.) and $0.003 \%$ hydrogen peroxide (Fisher Scientific Co., Pittsburgh, PA). After 3 min, the peroxidase reaction was terminated by flooding with $0.01 \mathrm{M}$ sodium citrate, $\mathrm{pH} 3.0$, and the slides were thrice washed in PBS and mounted in 50\% glycerol in PBS. In addition, glomeruli from remaining cortex were isolated by a standard sieving technique (17). Glomerular suspensions were washed twice in PBS, and glomeruli were resuspended at 12 different dilutions in duplicate in microplate wells (Dynatech Laboratories, Inc., Alexandria, VA) in a solution of 2,2azino-di(3-ethyl-benzthiazoline)sulfonic acid (Zymed Laboratories, South San Francisco, CA) diluted 1:50 in 0.1 M sodium citrate, $\mathrm{pH} 4.2$, containing $0.03 \% \mathrm{H}_{2} \mathrm{O}_{2}$. The optical density at $410 \mathrm{~nm}$ was monitored as a function of time in a microplate reader (Dynatech Laboratories). The change in optical density per unit time over the linear phase of the reaction was correlated with the dilution of glomerular suspension. The units of enzymatic activity (expressed as millienzyme units, where $1 \mathrm{EU}$ results in a change in absorbance of 1.0 in $1 \mathrm{~min}$ ) per glomerulus were computed from the regression of the rate of change in optical density versus the number of glomeruli enumerated by direct counting. Similarly, serum samples from each rat were assayed for peroxidase activity in microwell plates.

Induction of nephrotic syndrome. Bovine $\gamma$-globulin (BGG, U.S. Biochemicals, Cleveland, $\mathrm{OH}$ ) was rendered cationic (c) by substitution with ethylene diamine (Fisher Scientific Co.) in the presence of 1-ethyl-3-[3-dimethylaminopropyl]-carbodiimide (Sigma Chemical Co.) (17-19). Male Sprague-Dawley rats (Zivic-Miller Farms), $200 \mathrm{~g}$, given free access to food and water, were immunized s.c. with $1 \mathrm{mg}$ of cBGG in Freund's complete adjuvant (Difco Laboratories, Inc., Detroit, MI) and challenged intravenously with cBGG (17). For moderate proteinuria, five increasing daily i.v. injections of $1,2,4,6$, and $8 \mathrm{mg}$ of cBGG were used, whereas $2,4,6,8$, and $10 \mathrm{mg}$ of $\mathrm{cBGG}$ were given to induce heavy proteinuria, both starting $7 \mathrm{~d}$ after priming. In this model, nephrotic syndrome develops independently of circulating leukocytes and serum complement (19).

Other rats were given a single intraperitoneal injection of puromycin aminonucleoside (ICN Biochemicals, Cleveland, $\mathrm{OH}$ ), as a $30 \mathrm{mg} /$ $\mathrm{ml}$ solution in PBS, at a dose of $15 \mathrm{mg} / 100 \mathrm{~g}$ body weight (20).

Enzyme therapy and sacrifice. Nagarse and chymopapain (Sigma Chemical Co.) were each substituted by incubation at $5 \mathrm{mg} / \mathrm{ml}$ in $0.1 \mathrm{M}$ $\mathrm{K}_{2} \mathrm{CO}_{3} / \mathrm{KHCO}_{3}$ buffer at $\mathrm{pH} 8.5$ containing $2.5 \mathrm{mg} / \mathrm{ml} 5$-hydroxysuccinimido biotin (Sigma Chemical Co.) for $2 \mathrm{~h}$ at $25^{\circ} \mathrm{C}(21$ ). After extensive dialysis against sodium bicarbonate buffer, the activities of $b$ - and n-nagarse and chymopapain were assayed by measuring tyrosine release from a standard casein (Sigma Chemical Co.) preparation (22). The activities of $b$ - and n-chymopapain were also measured by titrimetric end-point assay of the synthetic peptide substrate $N$ - $\alpha$-benzoyl-Larginine ethyl ester (Sigma Chemical Co.) (23). Concentrations of the enzymes were adjusted so that equal activities of $b$ - and $n$ - forms were administered in vivo. Rats were injected i.p. with $2.5 \mathrm{ml}$ of plain saline or saline containing $6.25 \mathrm{U}$ of nagarse (n-nagarse $1.73 \mathrm{U} / \mathrm{mg}$ and b-nagarse $1.65 \mathrm{U} / \mathrm{mg}$ ) and $3 \mathrm{U}$ of chymopapain (n-chymopapain $0.98 \mathrm{U} /$ $\mathrm{mg}$ and b-chymopapain $0.84 \mathrm{U} / \mathrm{mg}$ ) as either $\mathrm{n}$ - or b- enzymes twice each day for $5 \mathrm{~d}$, beginning $36 \mathrm{~h}$ after the last antigen challenge, or $6 \mathrm{~d}$ after puromycin injection. Some rats also received a single daily i.v. injection of $1 \mathrm{mg}$ of avidin A (Sigma Chemical Co.) $1 \mathrm{~h}$ before the first i.p. injection of enzymes; among these, 10 rats were given $4.5 \mathrm{mg}$ of free biotin i.p. with the b-proteases to saturate avidin sites and block b-protease targeting. Inactivated enzymes were administered to some rats.
Rats were anesthetized with ether and exsanguinated by aortic puncture $18-20 \mathrm{~h}$ after the last i.p. injection.

Chymopapain and nagarse were inactivated by dissolving each enzyme in $6 \mathrm{M}$ guanidine $\mathrm{HCl}, 10 \mathrm{mM}$ Tris $\mathrm{HCl}, \mathrm{pH} 7.0$, to a final concentration of $10 \mathrm{mg} / \mathrm{ml}(24,25)$. After nitrogen was bubbled through the solutions, dithiothreitol (International Biotechnologies, Inc., New Haven, CT) was added to a final concentration of $30 \mathrm{mM}$. The mixture was then incubated at $37^{\circ} \mathrm{C}$ for $3 \mathrm{~h}$ and iodoacetamide was added to a final concentration of $33 \mathrm{mg} / \mathrm{ml}$; an equal mass of solid Tris base was added simultaneously to prevent rapid $\mathrm{pH}$ change (25). The $\mathrm{pH}$ of the mixture was adjusted to 8.0 with $1 \mathrm{M}$ Tris base. After 30 $\min$. at $4^{\circ} \mathrm{C}$, the solution was exhaustively dialyzed against PBS. Active $(0-500 \mu \mathrm{g} / \mathrm{ml})$ and inactive $(0-1,500 \mu \mathrm{g} / \mathrm{ml})$ chymopapain at varying concentrations were incubated at $25^{\circ} \mathrm{C}$ for $60 \mathrm{~min}$. with $\mathrm{N}-\alpha$ benzoylDL-arginine p-nitroanilide (Sigma Chemical Co.) and active (0-500 $\mu \mathrm{g} / \mathrm{ml})$ and inactive $(0-1,500 \mu \mathrm{g} / \mathrm{ml})$ nagarse at varying concentrations were incubated with $N$-acetyl-L-alanine $p$-nitroanilide (Sigma Chemical Co.) at $25^{\circ} \mathrm{C}$ for $60 \mathrm{~min}$. The chromogenic peptide substrates were first dissolved at $43.5 \mathrm{mg} / \mathrm{ml}$ in dimethylsulfoxide (Sigma Chemical Co.) and then the change in optical density at $405 \mathrm{~nm} / \mathrm{min}$ divided by the micromolar extinction coefficient of $p$-nitroaniline $\left(5.495 \times 10^{-3}\right)$ was taken as the enzymatic activity. Active chymopapain had a specific activity of $0.957 \mathrm{U} / \mathrm{mg}$, whereas inactivated chymopapain had 0.096 $\mathrm{U} / \mathrm{mg}$ ( $90 \%$ inhibition). Active nagarse had a specific activity of 1.67 $\mathrm{U} / \mathrm{mg}$, whereas inactivated nagarse had $<0.034 \mathrm{U} / \mathrm{mg}$ (98\% inhibition).

Urinalysis. Proteinuria values recorded in all tables were measured by sulfosalicylic acid (SSA)-induced turbidity (26); turbidities of urine samples collected from rats placed in metabolic cages overnight were interpolated into a standard curve with known concentrations of bovine serum albumin (Sigma Chemical Co.) in PBS. The protein concentration in the urine samples was multiplied by the sample volume and by 24 divided by the duration of the collection period in hours (never less than 16) to express the mass of protein excreted per day. Urine collection from each rat was started $24 \mathrm{~h}$ after the last i.v. antigen challenge in rats given $\mathrm{cBGG}$, and $6 \mathrm{~d}$ after injection in rats given puromycin (pretreatment proteinuria) and $2 \mathrm{~h}$ after the last i.p. enzyme dose (post-treatment proteinuria) in all rats. Urinary protein electrophoresis was performed in agarose and SDS-PAGE. For the latter, urine was dialyzed against 4 changes of a 20 -fold volume of $\operatorname{PBS}(27,28)$.

ELISA for urinary albumin excretion. Microwell plates (Immunoplate Maxisorp, Nunc, Kamstrup, Denmark) were coated for $16 \mathrm{~h}$ at $37^{\circ} \mathrm{C}$ with goat IgG (U. S. Biochemicals) in PBS, containing $2.5 \mu \mathrm{g} / \mathrm{ml}$ of antibody specific for rat albumin. Subsequently, a solution of 10 $\mathrm{mg} / \mathrm{ml}$ bovine serum albumin (U. S. Biochemicals) in PBS was used to wash the plate twice, and this solution was also incubated in the wells for $1 \mathrm{~h}$ at $37^{\circ} \mathrm{C}$ to block nonspecific sites. After three additional washes, $100 \mu$ l of standards $(0-3,000 \mu \mathrm{g} / \mathrm{ml})$ of rat serum albumin in PBS (Cappel Laboratories, Cochraneville, PA) or unknown rat urine samples (diluted 1:30 in PBS) were added to duplicate wells. After a 1-h incubation at $25^{\circ} \mathrm{C}, 100 \mu \mathrm{l}$ of a $200 \mu \mathrm{g} / \mathrm{ml}$ solution of labeled rat albumin (biotinylated in exactly the same manner as the peroxidase and protease enzymes, above) was added to each well. In some cases, varying amounts of $10 \%$ trichloroacetic acid-soluble fractions of digests of rat albumin, treated in vitro for $3 \mathrm{~h}$ at $37^{\circ} \mathrm{C}$ with $2 \mathrm{U}$ of nagarse and $1 \mathrm{U}$ of chymopapain $\left(60 \%\right.$ of the $\mathrm{OD}_{280}$ was soluble in $10 \%$ trichloroacetic acid), were added to wells coated with anti-rat albumin instead of standard or sample. After another 1-h incubation at $25^{\circ} \mathrm{C}$ and three washes with PBS, binding of labeled rat albumin was detected by incubation with alkaline-phosphatase-conjugated Extravidin (Sigma Chemical Co., diluted 1:1,000 in PBS), a modified avidin A product with low nonspecific binding characteristics. Finally, after 30 min of incubation at $25^{\circ} \mathrm{C}$ and three washes with PBS, $4 \mathrm{mg} / \mathrm{ml} p$-nitrophenylphosphate in $50 \mathrm{mM}$ glycine, $1 \mathrm{mM} \mathrm{MgCl}_{2}, \mathrm{pH} 10.5$ was added. Product generation was followed by absorbance at $410 \mathrm{~nm}$ in a microplate photometer (Dynatech Laboratories).

Glomerular hemodynamics. Clearance of $\left[{ }^{3} \mathrm{H}\right]$ inulin and $\left[{ }^{14} \mathrm{C}\right] \mathrm{p}-$ amino-hippurate (PAH, New England Nuclear, Boston, MA) was mea- 
sured in randomly selected rats (17). Briefly, rats were anesthetized with $50 \mathrm{mg} / \mathrm{kg}$ pentobarbital i.p., placed on a thermocontrolled pad, and tracheotomized. The femoral and jugular veins and the bladder were catheterized, and a mixture of $1 \mu \mathrm{Ci} / \mathrm{ml}$ inulin and $0.75 \mu \mathrm{Ci} / \mathrm{ml}$ PAH in PBS was infused into the jugular vein at $1.5 \mathrm{ml} / \mathrm{h}$. After a 20-min equilibration period, three separate 20 -min clearance periods were designated. All urine from each period and a $100-\mu l$ blood sample from the femoral vein at the midpoint of each urine collection were counted for ${ }^{3} \mathrm{H}$ and ${ }^{14} \mathrm{C}$ in a liquid scintillation counter (Beckman Instruments, Inc., Fullerton, CA). At the end of the clearance study a renal vein blood sample was obtained to calculate PAH extraction; PAH clearance was divided by extraction to estimate renal plasma flow.

Immunofluorescence microscopy. Cryostat sections of renal cortex excised after sacrifice were washed in PBS for 5 min, fixed in acetone for $1 \mathrm{~min}$, washed in PBS for $5 \mathrm{~min}$, and overlaid with conjugated goat antisera specific for rat IgG (rhodamine conjugate), rat $\mathrm{C} 3$ (fluorescein conjugate), or bovine IgG (fluorescein conjugate) (all from U. S. Biochemicals) for $30 \mathrm{~min}$, followed by a 10-min wash in PBS and mounting in 50\% glycerol in PBS (17). The antisera all gave appropriate reactivity without cross-reactions when tested by Ouchterlony double immunodiffusion and by application to cryostat sections of kidneys from rats with autologous and heterologous phases of nephrotoxic serum nephritis, rats given a single $10-\mathrm{mg}$ injection of $\mathrm{CBGG}$, and decomplemented rats with nephrosis induced by cBGG (19). Coded sections were examined independently by two observers and graded on a scale of 0 to $4+$; the occasional minor discrepancies in the two scores were resolved by consensus before decoding. The sum of all semiquantitative scores for all rats within each group was divided by the number of observations to establish the mean fluorescence score; the number of rats scored positive in each group was also recorded.

Electron microscopy. Small $\left(1 \mathrm{~mm}^{3}\right)$ pieces of renal cortex were embedded in Spurr's epoxy after fixation in $2.5 \%$ glutaraldehyde and after fixation in $1 \% \mathrm{OsO}_{4}$ (all materials from Polysciences, Inc. Warrington, PA). Ultrathin 50-nm sections were cut, picked up on carbon-coated nickel grids, and stained with uranyl acetate and lead citrate $(17,19)$. Coded specimens were examined in an electron microscope (model 400, Philips Medical Electronics Division, Piscataway, $\mathrm{NJ}$ ). Five or more randomly selected fields from each rat were subject to morphometric analysis for the number and size of electron dense deposits with a computerized image analysis system (SigmaScan, Jandel Scientific, Corte Madera, CA).

Serum studies. Assay of anti-cBGG antibody was performed as previously described $(17,19)$. Rat serum was serially diluted from 1:40 to $1: 10,240$ in PBS; duplicate $100-\mu 1$ samples at each dilution were incubated in microwell plates precoated with $\mathrm{CBGG}$ and blocked with bovine albumin for $1 \mathrm{~h}$ at $25^{\circ} \mathrm{C}$. After three washes, $100-\mu \mathrm{l}$ aliquots of alkaline phosphatase conjugated goat anti-rat IgG (U. S. Biochemicals), diluted 1:500, were added to each well. After a further incubation at $25^{\circ} \mathrm{C}$ for $1 \mathrm{~h}$, the plates were washed and $100 \mu \mathrm{l}$ per well of $4 \mathrm{mg} / \mathrm{ml}$ p-nitrophenylphosphate (Sigma Chemical Co.) in $10 \mathrm{mM}$ glycine/ $\mathrm{NaOH}$ buffer, $\mathrm{pH} 10.5$, was added. The reaction was monitored in a microplate photometer, and the amount of antibody was expressed as the optical density of undiluted antiserum at $410 \mathrm{~nm}$ extrapolated from the regression of optical density versus $\log$ serum concentration.

Serum protein electrophoresis was performed in agarose gel at $\mathrm{pH}$ 8.5 and in $7 \%$ polyacrylamide gel in the presence of sodium dodecyl sulfate $(27,28)$. Densitometry (GS300, Hoefer Scientific Instruments, San Francisco, CA) of protein bands stained with Coomassie Blue was quantified by integration of the areas under the peaks (Bioquant IV, $R$ \& M Biometrics, Inc., Nashville, TN); each peak was expressed as percent total stained area. The concentrations of total protein, albumin, globulins, creatinine, cholesterol, triglycerides, oxaloacetate- and pyruvate-transaminases, lactic dehydrogenase, and creatine phosphokinase were determined by standard automated procedures in our Clinical Chemistry Laboratory (Chem-1 Analyzer, Technicon Instruments Corp., Tarrytown, NY).

Kinetics of clearance of functional proteases from the circulation.
Cohorts of normal or nephrotic rats not used for other studies were given full courses of treatment with b- or n-enzymes, with or without avidin, or sham saline injections. At intervals, animals were bled and protease activities in the timed serum samples were assayed $(22,23)$ and expressed as units per milliliter of serum. Half-times were computed from regressions of $\log$ (activity) versus time.

\section{Results}

Pilot studies. In all glomerular suspensions from all rats, optical density was a linear function of time, up to $10 \mathrm{~min}$ of observation (all $r^{2}$ ranged from 0.976 to 0.988 ; all $P<0.001$ ). For each rat observed, the optical density developed at $10 \mathrm{~min}$ (maximal value in linear phase of reaction) was a linear function of the number of glomeruli added to a standard substrate solution, for each of 12 dilutions in duplicate ( $r^{2}$ ranged from 0.838 to 0.946; all $P<0.01$ ). The slope of this regression from each individual animal was taken as the enzyme activity ( $\mu \mathrm{EU}$ per glomerulus), and the mean slope of each of the six animals in each group recorded (Table I). The intercepts of the individual regression curves were uniformly $<0.02$, whereas the maximums were in the $0.5-0.6$ range. All six rats given avidin and b-peroxidase had dense diaminobenzidine aggregates along glomerular capillary walls by light microscopy, whereas none of the rats given avidin plus n-peroxidase, saline plus b-peroxidase or avidin plus saline had glomerular staining above the background observed in normal rat glomeruli. Furthermore, glomeruli isolated from rats given avidin plus b-peroxidase contained $65 \%$ more peroxidase activity than glomeruli from rats given saline and b-peroxidase and $73 \%$ more activity than glomeruli from rats given avidin and n-peroxidase (both $P$ 's $<0.01$, Table I). These results demonstrate that avidin, a naturally cationic protein, can target functional enzyme to the glomerular capillary wall if the enzyme is biotinylated.

Effect of proteases on cBGG-induced nephrosis with moderate proteinuria. All groups of rats had similar initial proteinuria (overall mean $85 \pm 12 \mathrm{mg} / 24 \mathrm{~h}, F$ among the groups $=1.2$ ) after the last antigen challenge. After therapy, rats given saline for 5 $\mathrm{d}$ had the greatest proteinuria, $51 \pm 10 \mathrm{mg} / 24 \mathrm{~h}$ (Table II). All groups given proteolytic enzymes had significantly less protein excretion than the saline-treated rats, but among these three groups, rats given avidin and b-proteases had significantly less proteinuria than rats given avidin and n-proteases or rats given

Table I. Targeting of Functional Horseradish Peroxidase to the Glomerulus

\begin{tabular}{|c|c|c|c|}
\hline Injection & $\begin{array}{l}\text { No. of } \\
\text { rats }\end{array}$ & $\begin{array}{c}\text { Glomerular } \\
\text { peroxidase activity }\end{array}$ & $\begin{array}{l}\text { Median (range) of } \\
\text { squared correlation } \\
\text { coefficients }\end{array}$ \\
\hline \multicolumn{4}{|c|}{$\mu E U /$ glomerulus $\pm S D$} \\
\hline Avidin $+n$-peroxidase & 6 & $10.8 \pm 2.9^{\ddagger}$ & $0.89(0.85-0.93)$ \\
\hline Avidin + b-peroxidase & 6 & $18.7 \pm 4.2^{\ddagger \S}$ & $0.92(0.89-0.95)$ \\
\hline Saline + b-peroxidase & 6 & $11.3 \pm 2.3^{\ddagger}$ & $0.87(0.84-0.90)$ \\
\hline Avidin + saline & 6 & $8.6 \pm 1.8$ & $0.91(0.89-0.94)$ \\
\hline None & 6 & $9.2 \pm 2.5$ & $0.87(0.85-0.89)$ \\
\hline
\end{tabular}

* Squares of the correlation coefficients of the regression between enzyme activity $(\mathrm{OD} / \mathrm{min})$ and number of glomeruli at 12 different dilutions of the glomerular suspension, in duplicate. ${ }^{*}$ Significantly different from normal rats $(P<0.05)$. ${ }^{8}$ Significantly different from both other (nontargeted) groups given peroxidase $(P<0.01)$. 
Table II. Effects of Targeted Protease in Active Serum Sickness Glomerulonephritis with Moderate Proteinuria

\begin{tabular}{lcccccc}
\hline & & & \multicolumn{3}{c}{ Glomerular immune deposits* } \\
\cline { 5 - 7 } Treatment & $\begin{array}{c}\text { Number } \\
\text { of rats }\end{array}$ & Proteinuria & BGG & rat IgG & rat C3 \\
\hline & & $m g /$ day $\pm S D$ & & & \\
$\begin{array}{c}\text { Saline } \\
\begin{array}{c}\text { Avidin } \\
+ \text { b-protease }\end{array}\end{array}$ & 7 & $51.3 \pm 10.4$ & $7(2.8+)$ & $7(3.0+)$ & $6(2.8+)$ \\
$\begin{array}{c}\text { Avidin } \\
+ \text { n-protease }\end{array}$ & 7 & $38.8 \pm 8.5^{\| \prime}$ & $7(2.7+)$ & $7(2.3+)$ & $7(1.8+)$ \\
$\begin{array}{c}\text { B-protease } \\
\text { only }\end{array}$ & 4 & $37.8 \pm 13.1^{\| \prime}$ & $4(3.0+)$ & $4(1.8+)$ & $2(0.9+)$ \\
\hline
\end{tabular}

* Data are the number of rats positive (and mean semiquantitative immunofluorescence intensity score of all rats in each group). ${ }^{\ddagger} P$ $<0.01$ vs. other protease groups, and $P<0.001$ vs. saline group by Fisher's protected $t$ test in ANOVA. ${ }^{\S} \chi^{2}=5.6, P<0.01$ vs. saline group for number of rats positive (relative intensity of immunofluorescence was not considered in the analysis). " $P<0.05$ vs. saline group by Fisher's protected $t$ test in ANOVA.

b-proteases without avidin. Moreover, the rats given avidin and b-proteases revealed glomerular rat IgG and $\mathrm{C} 3$ by immunofluorescence less frequently than saline-treated rats (Table II, Fig. 1); the other two groups given untargeted protease had no decrease in the frequency of glomerular immune deposits compared to the saline-treated controls, although the intensities for rat IgG and C3 were appreciably less in these groups than in saline-treated rats. Moreover, we were able to demonstrate, using fluorescein-conjugated antibodies, that avidin is present in the glomeruli of rats given targeted proteases in a distribution identical to that seen with rhodamine conjugated anti-rat IgG, thereby demonstrating localization of avidin to the site of glomerular deposits. Serum antibody titers against
cBGG and total serum protein concentrations were indistinguishable among all the groups. Enzyme activity could not be detected in urine collected during the $20 \mathrm{~h}$ after the last enzyme dose.

Effect of proteases on $c B G G$-induced nephrosis with heavy proteinuria. Despite statistically indistinguishable initial levels of protein excretion prior to the onset of therapy, rats treated with avidin and b-proteases had $60 \%$ less proteinuria after $5 \mathrm{~d}$ of therapy than did rats given saline or avidin alone $(P<0.001$, Table III). Rats given untargeted proteases, whether avidin and n-proteases, biotin-saturated avidin plus b-proteases, or b-proteases alone, had more modest reductions in urinary protein that were significantly greater than the level observed in nephrotic rats given targeted protease $(P<0.01)$. Protease activity in dialyzed urine from treated rats was indistinguishable from that in normal rats (data not shown). Urine protein electrophoreses, in both polyacrylamide and agarose, showed that most of the proteinuria $(\sim 85 \%)$ was due to intact albumin, without evidence of degradation to smaller polypeptides (data not shown). Finally, recovery of known amounts of protease activity added to saline or to dialyzed nephrotic or normal rat urine was $98-104 \%(F=0.78)$, indicating that no protease inhibitors are present in urine.

There were no differences in the very intense immune deposits of BGG, rat IgG or C3 observed by immunofluorescence among these groups given high doses of cBGG (data not shown). However, rats treated with avidin and b-protease had distinctly fewer and smaller electron dense deposits, which occupied less aggregate space than in rats given biotin-saturated avidin and b-protease (Table III, Fig. 2). Deposits present in targeted or untargeted native protease-treated rats were also smaller in size than those in the group treated with saline, but the difference did not attain significance. The mean aggregate size of deposits per unit basement membrane length in rats given biotin-saturated avidin and biotinyl enzymes was not different from that in rats given saline. Overall, there was a significant correlation between urinary protein excretion and
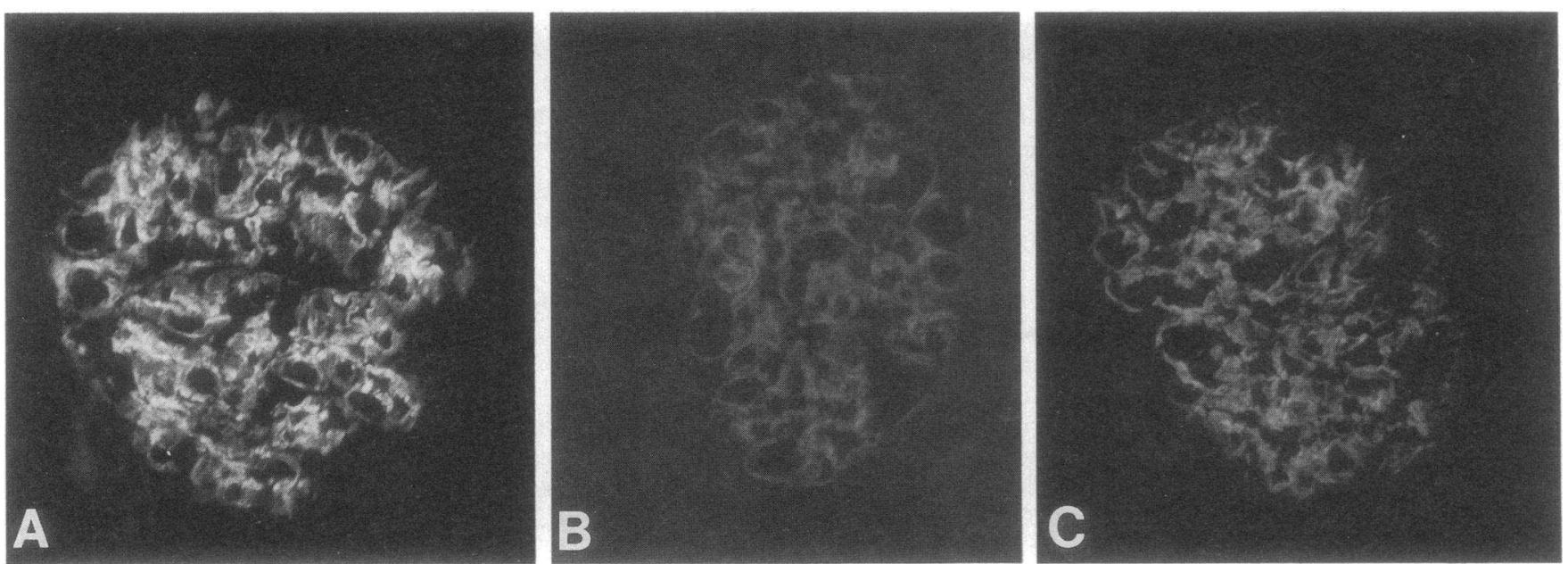

Figure 1. Targeted protease reduces glomerular deposits in experimental glomerulonephritis. Immunofluorescence micrographs show rat IgG staining in glomeruli from rats rendered nephrotic by immunization and challenge with cationic bovine gamma globulin and then treated for $5 \mathrm{~d}$ with $(A)$ saline, $(B)$ avidin and biotinyl protease, or $(C)$ avidin and native protease. The biotinyl protease targeted by avidin to the glomerular capillary wall, the site of the immune deposits, significantly reduced immune deposits $(B)$ compared with nephrotic rats given saline $(A)$. The frequency distribution of $\mathrm{IgG}$ in nephrotic rats given untargeted protease $(C)$ was similar to saline-treated rats $(A)$, but the intensity was less, more comparable to that in rats treated with targeted protease $(B)$. Biotinyl protease given without avidin (not shown) had an intermediate effect similar to that of native protease given with avidin $(C) . \times 350$. 
Table III. Effects of Targeted Protease in Active Serum Sickness Glomerulonephritis with Severe Proteinuria*

\begin{tabular}{|c|c|c|c|c|c|}
\hline \multirow[b]{2}{*}{ Treatment } & \multirow{2}{*}{$\begin{array}{l}\text { No. of } \\
\text { rats }\end{array}$} & \multicolumn{2}{|c|}{ Proteinuria } & \multirow{2}{*}{$\begin{array}{c}\text { Electron } \\
\text { microscopic } \\
\text { deposits }^{\ddagger}\end{array}$} & \multirow{2}{*}{$\begin{array}{c}\text { Serum } \\
\text { cholesterol }\end{array}$} \\
\hline & & Initial & Final & & \\
\hline & . & \multicolumn{2}{|c|}{$m g / d$} & $n m$ & $\mathrm{mg} / d l$ \\
\hline Saline & 16 & $204 \pm 16$ & $89.0 \pm 11.4$ & $35.2 \pm 26.7$ & $131 \pm 10.3$ \\
\hline Avidin + b-protease & 17 & $218 \pm 21$ & $36.1 \pm 7.1^{\S 11}$ & $19.4 \pm 9.3^{\prime}$ & $86 \pm 6.1^{5}$ \\
\hline Avidin + n-protease & 16 & $208 \pm 17$ & $56.2 \pm 6.0^{* *}$ & $23.6 \pm 7.4$ & $111 \pm 7.2$ \\
\hline $\begin{array}{l}\text { Avidin, free biotin, } \\
\text { and b-protease }\end{array}$ & 10 & $179+17$ & $65.9+11.5$ & $47.4+17.5$ & $96+74^{* *}$ \\
\hline B-protease only & 10 & $210 \pm 12$ & $69.5 \pm 11.8$ & not done & $109 \pm 7.4^{* *}$ \\
\hline Avidin only & 10 & $188 \pm 10$ & $94.9 \pm 14.3$ & not done & $127 \pm 10.5$ \\
\hline
\end{tabular}

* Data are means \pm SD. ${ }^{\ddagger}$ Data are the total area occupied by immune deposits $\left(\mathrm{nm}^{2}\right)$ per unit length of glomerular basement membrane (nm). Randomly selected rats were studied ultrastructurally. ${ }^{8}$ Different from saline/no avidin (top row) and avidin only (bottom row) $(P \geq .001)$ by Fisher's protected $t$ test in ANOVA $(F=4.75, P \leq 0.001)$. " Different from all non-targeted enzymetreated groups $(P<0.01)$ by Fisher's protected $t$ test in ANOVA $(F=4.75, P$ $\leq 0.001)$. 'These rats $(n=8)$ are equivocally different from saline/no avidin ( $n$ $=8, t=1.7, P<0.1)$ and different significantly from biotin, saturated avidin + b-protease $(n=6, t=2.8, P<0.01)$ by Fisher's protected $t$ test in ANOVA $(F=2.9, P<0.06){ }^{* *}$ Different from saline/no avidin and avidin only $(P$ $<0.05)$ by Fisher's protected $t$ test in ANOVA $(F=4.75, P \leq 0.001)$.

the area of immune deposits detected ultrastructurally per unit length of basement membrane $\left(r^{2}=0.63, P<0.01\right)$.

Protease treatment also significantly reduced the hyperlipidemia accompanying the nephrotic syndrome. While salinetreated rats had a mean serum cholesterol of $131 \pm 10.3 \mathrm{mg} / \mathrm{dl}$ (vs. a normal age-matched rat serum cholesterol of $57 \pm 8.1 \mathrm{mg} /$ $\mathrm{dl}, P<0.001$ ), rats given biotin-saturated avidin and b-proteases, avidin and n-proteases, or b-proteases had $96 \pm 7.4$, $111 \pm 7.2$, and $109 \pm 7.4 \mathrm{mg} / \mathrm{dl}$, respectively, compared to $86 \pm 6.1 \mathrm{mg} / \mathrm{dl}$ in the rats given targeted enzymes. The cholesterol levels in two of the three untargeted protease treated groups were significantly less than in the saline-treated rats $(P$ $<0.05$ for b-protease and $P<0.01$ for biotin-saturated avidin plus b-protease, both vs. saline), and the group given avidin and b-protease was also significantly different from the group given avidin and $\mathrm{n}$-protease $(P<0.05)$.

Normal rats given proteases had levels of protease activity in serum that were significantly higher than in those given saline $4 \mathrm{~h}$ after the last i.p. injection (Table IV). Furthermore, rats given targeted protease (avidin and b-protease) had lower serum protease activity $(P<0.05)$ than rats given untargeted proteases (avidin and n-protease, or b-protease alone-latter not shown). Kinetic studies showed that serum caseinolytic activity decreased with a half-life of $19-23 \mathrm{~h}$ in rats given protease and returned to normal by $56 \mathrm{~h}$ after the last enzyme injection. Thus, natural serum antiprotease activity is insufficient to neutralize the protease activity of the injected enzymes in the amounts given.

Despite the presence of active proteases in serum, serum electrophoresis patterns did not differ between enzyme-treated and saline-treated nephrotic rats, and albumin and total protein concentrations were the same among the nephrotic groups irrespective of treatment. Anti-BGG antibody levels in sera from protease-treated and saline-treated nephrotic rats where disease was induced by cBGG were significantly elevated, and were indistinguishable from each other in terms of titer and slope of the optical density versus log (serum concentration) regression (Fig. 3).
Toxicity studies. Nephrotic rats treated with saline, untargeted protease, or targeted protease had serum concentrations of glutamate-oxaloacetate transaminase, lactic dehydrogenase, or creatine phosphokinase no different from normal rats. Hence, no serum enzymes associated with cytolysis or toxicity were increased in rats treated with proteases. Moreover, at sacrifice, there were no signs of peritonitis, intestinal adhesions, necrosis, or hemorrhage in enzyme treated rats.

Finally, we investigated whether targeted protease therapy affects glomerular hemodynamics (Table V). As previously described (17), neither renal plasma flow nor glomerular filtration rate in nephrotic rats differed from normal age-matched controls. The glomerular filtration rate in protease-treated nephrotic rats did not significantly differ from that in salinetreated nephrotic rats or normal controls. Renal plasma flow in enzyme-treated nephrotic rats was also the same as in salinetreated nephrotic rats and normal controls.

Necessity of enzymatic activity for efficacy of protease therapy. In a separate experiment, we used inactive nagarse and chymopapain for comparison with active enzymes. Among rats with nephrosis induced by $\mathrm{CBGG}$, those treated with active proteases had significantly less proteinuria at the end of treatment than those treated with inactive proteases (Table VI). Urinary albumin excretion was also different $(P<0.001)$ in rats treated with active enzymes $(46.6 \pm 7.7 \mathrm{mg} / \mathrm{d})$ vs. those given inactive proteases $(85.8 \pm 4.2 \mathrm{mg} / \mathrm{d})$. Protein excretion in rats treated with active and inactive enzymes was similar, respectively, to that in nephrotic rats treated with active enzymes and saline in previous experiments. Moreover, the 5-d protein excretion (the integral under the curve of proteinuria as a function of time) also was significantly lower in rats treated with active protease $(892 \pm 102 \mathrm{mg})$ than in rats given inactive protease $(1,023 \pm 96.7 \mathrm{mg}, P \leq 0.01)$. Active, but not inactive, enzymes also reduced serum cholesterol and creatinine levels associated with nephrosis. In this short-term experiment, although modest hypoalbuminemia did develop in nephrotic rats, no differences in serum albumin concentration were observed between rats given active or inactive proteases.

Effect of enzymes on protein excretion in rats with puromycin amino-nucleoside nephrosis. As summarized in Table VII, targeted proteolytic enzymes, given by a regimen identical to that used for rats with cBGG-induced nephrosis, did not influence protein excretion or serum cholesterol concentration in rats with nephrosis induced by puromycin aminonucleoside. This experiment was concurrent with that summarized in Table VI, in which active proteases did ameliorate signs of cBGGinduced nephrosis.

Urinary albumin excretion. In order to exclude any spurious effect on proteinuria determination by SSA, we assayed urinary albumin excretion by ELISA in parallel with SSA. More than 60 rats were studied. Increasing amounts of unlabelled rat albumin, when preincubated in anti-rat albumincoated microwells, monotonically displaced binding of a fixed amount of biotin-labeled albumin. In fact, in three separate ELISA experiments the optical density was linear with the log of the concentration of unlabelled albumin added over the range of $0-3,000 \mu \mathrm{g} / \mathrm{ml}$ (all $r^{2} \geq 0.97$, all $P<0.001$ ). In addition, when standard curves were prepared with serial dilutions of trichloroacetic acid-soluble peptides derived from rat albumin digested in vitro with nagarse/chymopapain, equal in absorbance to serial dilutions of intact unlabelled rat albumin, similar curves relating optical density to concentration were 

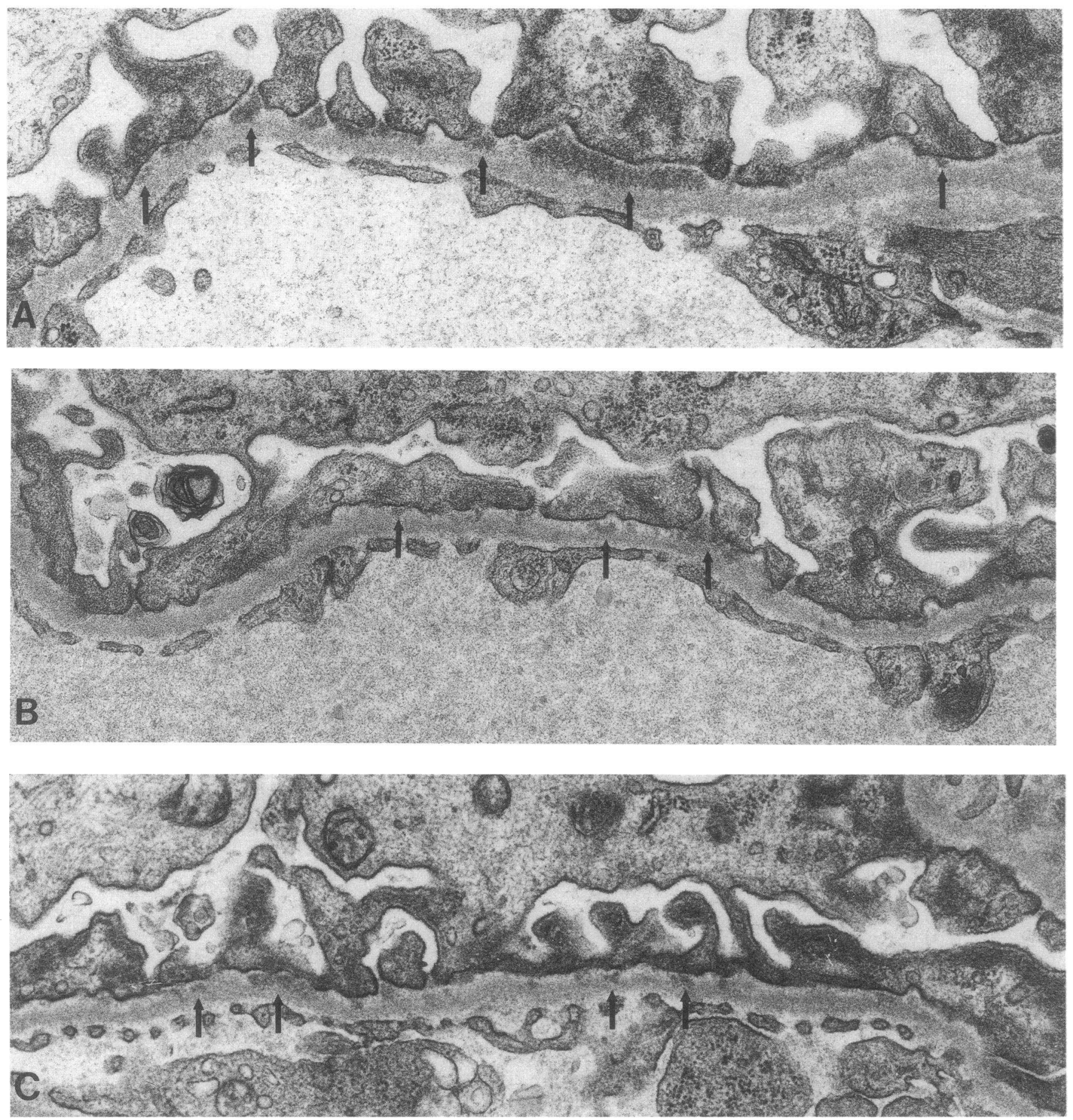

Figure 2. Electron-dense deposits in experimental nephrosis induced by cBGG are diminished by targeted protease. $(A)$ Nephrotic rats treated with saline for $5 \mathrm{~d}$ had numerous large, coalescent epimembranous deposits of uniform electron density (arrows). (B) Nephrotic rats treated with avidin and biotinyl protease had fewer deposits, which tended to be small. $(C)$ Nephrotic rats treated with avidin and native protease had intermediate numbers of variably sized, electron-dense deposits. $\times 31,350$.

obtained, and linear-least squares regression analysis of the apparent albumin concentrations with the peptides revealed that $88 \%$ of the displacement obtained with the whole molecule was obtained with the comparable mass of peptides (i.e., the slope was 0.88 , with an $r^{2}$ of 0.93 ).

Urine samples from all rats reported in Tables VI and VII and randomly selected rats from Table III were assayed by
ELISA for rat albumin content on two separate occasions. There were significant differences in albuminuria among rats with active serum sickness treated with active targeted proteases compared to those treated with inactive enzymes or saline, respectively $(P<0.01)$. However, no differences were observed among rats with puromycin nephrosis, whether treated or not. The results compared well with the values obtained by 
Table IV. Clearance of Active Enzyme from the Circulation of Normal Rats

\begin{tabular}{lccc}
\hline \multicolumn{1}{c}{ Treatment } & $\begin{array}{c}\text { No. of } \\
\text { rats }\end{array}$ & Initial activity* & Half-life \\
\hline & & $U / m l$ & $h$ \\
Avidin + b-protease & 5 & $120 \pm 11.5^{\ddagger \S}$ & 23.2 \\
Avidin + n-protease & 5 & $138 \pm 12.8^{\ddagger}$ & 19.1 \\
Avidin only & 5 & $38.3 \pm 6.2$ & NA $^{\|}$
\end{tabular}

* Mean activity $( \pm S D)$ measured $4 \mathrm{~h}$ after the last i.p. injection of protease. ${ }^{\ddagger} P<0.001$ vs. saline controls given avidin but no enzyme (bottom row) by Fisher's protected $t$ test in ANOVA. ${ }^{\$} P<0.05$ vs. rats given avidin plus native protease by Fisher's protected $t$ test in ANOVA. "Not applicable: enzyme activity did not change in these control rats.

SSA-induced turbidity by linear-least squares regression. The correlation coefficient comparing the two ELISA runs was similar and not statistically different $(F=0.02)$ from the correlation coefficients comparing each ELISA run with the SSA data (all $r^{2} \geq 0.83$, all $\left.P<0.001\right)$. Although both ELISA vs. SSA produced slopes significantly $(P<0.01)<1(0.86$ and 0.72$)$, the slope between the two ELISA determinations for each of the 40 specimens was nearly unity (1.05, $P=$ NS vs. 1.00$)$. Most likely, this is due to a selectivity index of $\sim 80 \%$, since the ELISA only detects albumin, whereas the SSA assay detects albumin and other proteins as well. Among randomly selected urines, when the total protein (by SSA) was multiplied by the fraction of the area under the densitometric tracing of urine protein electrophoresis occupied by albumin and plotted against the ELISA values for albuminuria, even better correlations (all $r^{2} \geq 0.92$, all $P<0.001$ ) were obtained. Hence, en-

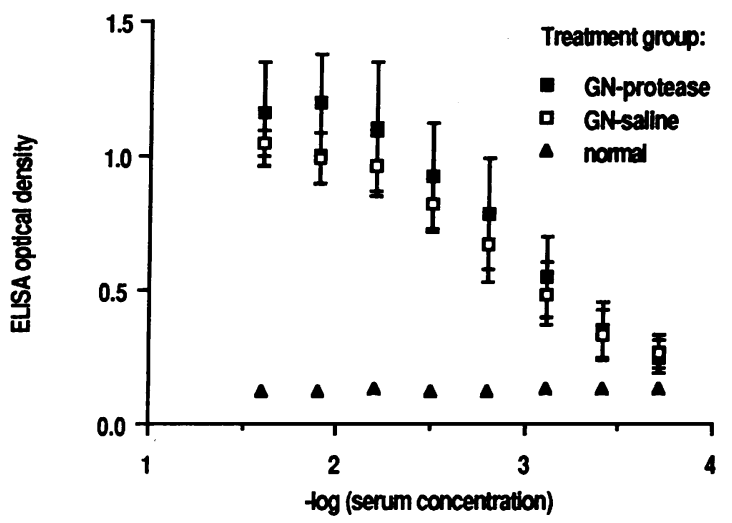

Figure 3. Targeted protease does not influence the level of serum antibody to cBGG sampled $17 \mathrm{~d}$ after priming. Serial dilutions of serum from nephrotic rats immunized and challenged with $\mathrm{cBGG}$ and treated with avidin and biotinyl protease ( $\square$ ) or saline ( $\square$ ), and serum from normal rats $(\Delta)$ were incubated in microwell plates coated with bovine $\gamma$-globulin. After addition of alkaline phosphatase conjugated goat anti-rat IgG antibody and p-nitrophenyl phosphate, chromogen was monitored at $410 \mathrm{~nm}$. In this ELISA, IgG antibody from nephrotic rats bound antigen-coated plates significantly more than did IgG from normal rats over a wide range of concentration. The antibody content of serum from nephrotic rats treated with targeted protease ( $\bullet$ ) did not differ from that of nephrotic rats treated with saline ( $\square$ ).
Table V. Effects of Targeted Protease on Glomerular Hemodynamics

\begin{tabular}{|c|c|c|c|c|c|}
\hline \multirow{2}{*}{$\begin{array}{c}\text { Severe } \\
\text { nephrotic } \\
\text { syndrome }\end{array}$} & \multirow[b]{2}{*}{ Treatment } & \multirow{2}{*}{$\begin{array}{l}\text { No. of } \\
\text { rats }\end{array}$} & \multicolumn{3}{|c|}{ Hemodynamics* } \\
\hline & & & GFR & RPF & GFF \\
\hline & & \multicolumn{4}{|c|}{$\mathrm{ml} / \mathrm{min}$} \\
\hline - & Saline & 6 & $3.1 \pm 1.2$ & $10.6 \pm 3.6$ & $0.29 \pm 0.12$ \\
\hline+ & Saline & 11 & $2.4 \pm 1.0$ & $11.3 \pm 4.1$ & $0.22 \pm 0.10$ \\
\hline+ & $\begin{array}{l}\text { Avidin } \\
\quad+b \text {-protease }\end{array}$ & 9 & $2.9 \pm 1.9$ & $12.8 \pm 4.7$ & $0.23 \pm 0.11$ \\
\hline
\end{tabular}

* Data are mean \pm SD glomerular filtration rate (GFR), renal plasma flow (RPF), and glomerular filtration fraction (GFF).

zyme therapy does not have a nonspecific effect on proteinuria as quantified by SSA. Moreover, treatment with active protease does not result in digestion of urine protein to a significant degree. Since the selectivity index in CBGG-induced nephrosis is variable, we consider total protein, best measured by SSA, the preferable method of assay; hence, all table entries are proteinuria determined by SSA.

\section{Discussion}

The data presented here extend earlier observations on the efficacy of protease therapy of experimental glomerulonephritis (14-16). In the current work we show that systemic administration of non-toxic doses of proteases, especially when targeted to the glomerular capillary wall, can remove glomerular immune deposits in a different model of immune complex glomerulonephritis, namely, active serum sickness induced by immunization and challenge of rats with cBGG. Decreased glomerular deposits were observed in some cases by both semiquantitative immunofluorescence and quantitative electron microscopy. Moreover, protease therapy improved several parameters of glomerular function in cBGG-induced nephrosis, including proteinuria and lipidemia.

In theory, several mechanisms could contribute to our observations. Urinary excretion of proteases along with albumin and other serum proteins could promote digestion of excreted protein already within the urine to the point of undetectability by turbidimetry. In this scenario, decreased proteinuria would be an analytical artefact rather than an indicator of improved glomerular permselectivity. This possibility can be excluded on several grounds. First, in the present study we could not detect increased proteolytic activity in the urine of rats given proteases, nor in our earlier studies (14) did a 4-h urine collection started immediately after protease injection contain detectable enzyme activity. Lack of enzymatic activity cannot be ascribed to the presence of protease inhibitors in the urine since the recovery of enzymatic activity when exogenous protease was deliberately added to normal or nephrotic rat urine uniformly exceeded $88 \%$. Secondly, peptides generated by incubation of rat serum in vitro with the enzymes used (14) were not observed in electrophoresis of urine from enzyme-treated rats, and the staining intensity of the albumin bands in such electrophoreses were consistent with the measured protein concentration. Moreover, such peptides are readily detected in the ELISA for urinary albumin, but were not detected in urine 
Table VI. Effects of Active vs. Inactive Targeted Protease in Active Serum Sickness Glomerulonephritis with Severe Proteinuria

\begin{tabular}{|c|c|c|c|c|c|c|c|}
\hline \multirow{2}{*}{$\begin{array}{l}\text { Glomerulonephritis } \\
\text { induction }\end{array}$} & \multirow{2}{*}{$\begin{array}{l}\text { Enzyme } \\
\text { treatment }\end{array}$} & \multirow{2}{*}{$\begin{array}{l}\text { Number } \\
\text { of rats }\end{array}$} & \multicolumn{3}{|c|}{ Serum concentration } & \multicolumn{2}{|c|}{ Proteinuria } \\
\hline & & & Cholesterol & Creatinine & Albumin & Initial & Final \\
\hline & & & \multicolumn{3}{|c|}{$m g / d l$} & \multicolumn{2}{|c|}{$m g / d a y$} \\
\hline $\mathrm{cBGG}$ & active & 8 & $101 \pm 8.5$ & $0.356 \pm 0.088$ & $2.63 \pm 0.16^{\ddagger}$ & $300 \pm 18^{\ddagger}$ & $56.6 \pm 9.8^{\ddagger}$ \\
\hline cBGG & inactive & 8 & $145 \pm 13^{*}$ & $0.544 \pm 0.113^{*}$ & $2.68 \pm 0.14^{\ddagger}$ & $299 \pm 19^{\ddagger}$ & $110 \pm 3.3^{*}$ \\
\hline none & none & 6 & $69 \pm 7.7$ & $0.283 \pm 0.075$ & $3.42 \pm 0.05$ & $9.3 \pm 3.9$ & $7.4 \pm 1.2$ \\
\hline
\end{tabular}

* Significant difference $(P<0.001)$ vs. control and cBGG glomerulonephritis treated with active enzymes $(F=11.8$ for cholesterol, 15.6 for creatinine, 10.8 for final proteinuria). ${ }^{\ddagger}$ Significant difference $(P<0.001)$ vs. control $(F \geq 10.8)$.

samples from rats given protease. Thirdly, although rats given b-proteases alone or avidin with n-proteases had higher serum levels of enzyme (potentially increasing filtered protease as well), these therapies were less effective at reducing proteinuria than was targeted enzyme (avidin plus b-proteases). Fourthly, this mechanism cannot explain the enzyme-induced reductions in glomerular immune deposits or the attenuation of hyperlipidemia and creatininemia. Fifthly, use of nonproteolytic enzymes capable of removing glomerular immune deposits induced with a polysaccharide antigen ameliorates proteinuria, despite absence of any proteolytic activity in the urine (29). Finally, the failure of proteases to ameliorate proteinuria and hyperlipidemia in puromycin nephrosis is inconsistent with an effect of protease on protein in the urine (as well as with a nonspecific effect of protease on glomerular permselectivity).

Another theoretical possibility to account for both diminished glomerular immune deposits and decreased proteinuria would be diminished glomerular delivery of immune reactants or decreased filtered load of serum proteins, either from reduced glomerular perfusion, sequestration, or catabolism. However, hemodynamic studies clearly showed no reduction in glomerular perfusion due to enzyme therapy. Moreover, we observed no change in the concentration, size distribution, or electrophoretic mobility of serum proteins in rats treated with proteases, and the serum antibody response to cBGG was identical in treated versus untreated nephrotic rats. Since the model of nephrosis used is complement independent (19), protease effects on the complement system could not have influenced proteinuria.

Proteases might enhance sequestration, catabolism, and/or clearance of circulating immune complexes preferentially compared to other serum proteins, thus resulting in diminished delivery to the glomerulus. Such an explanation is inconsistent with the observation that targeted enzymes were more effective than untargeted enzymes (b-proteases alone or avidin plus $n$ proteases) since lower serum enzyme levels were observed with targeted than with untargeted proteases.

The explanation for the therapeutic effect that we favor is the most direct, namely, that the administered enzymes degrade immune complexes in situ within glomeruli. Neither proteinuria nor glomerular immune deposits increase further after onset of nephrosis in the cBGG-induced model (17). Since, as already discussed, decrements in glomerular delivery of immune deposits are not plausible, we favor the concept that proteases accelerate removal of immune reactants already deposited in glomeruli. It is conceivable, as well, that enzyme treatment acts preferentially at the surface of glomerular im- mune deposits in such a way as to prevent expansion of the immune lattice, i.e., some of the efficacy of enzyme therapy may derive from inhibition of the growth of deposits rather than their dissolution. Enzyme action in situ in the glomerulus is the only interpretation which readily explains all the observations in this and previous publications (14-16, 29).

Enzymes deliberately targeted to the anionic glomerular capillary wall, where the cationic immune complexes bound, were more effective than untargeted enzymes at reducing glomerular deposits, decreasing proteinuria, and ameliorating hyperlipidemia and creatininemia. We therefore conclude that the interaction of avidin with biotinylated proteases is important, and propose that this interaction improves efficacy because the naturally cationic avidin targets the b-proteases to the same sites where cationic immune complexes have lodged, thereby promoting enzyme-substrate interaction. Targeting would also accelerate removal of b-proteases from the circulation by promoting their binding to avidin-containing sites such as the glomerular basement membrane. Such an effect can explain the lower enzyme activity observed in the sera of rats given targeted proteases compared to sera of rats given equal activity doses of nontargeted proteases.

In conclusion, we have demonstrated that proteases, especially when targeted, given systemically at nontoxic doses to nephrotic rats can ameliorate proteinuria, creatininemia, and hyperlipidemia, the cardinal features of the nephrotic syndrome. Targeted proteases can also reduce glomerular immune deposits. With further work and refinement it is conceivable that protease therapy could prove practical for patient therapy. In addition to its therapeutic potential, administration of appropriate enzymes to animals with experimental glomerulonephritis can be a useful tool for study of glomerular pathophysiology.

Table VII. Lack of Effect of Targeted Protease Therapy in Puromycin Aminonucleoside Nephrosis*

\begin{tabular}{lccccc}
\hline & & & \multicolumn{2}{c}{ Proteinuria } \\
\cline { 4 - 6 } Treatment & $\begin{array}{c}\text { Number } \\
\text { of rats }\end{array}$ & Serum cholesterol & Initial & Final \\
\hline & & $m g / d l$ & & \multicolumn{2}{c}{$m g / d$} \\
Enzymes & 8 & $272 \pm 14$ & $304 \pm 15$ & $230 \pm 20$ \\
Saline & 8 & $300 \pm 10$ & $328 \pm 27$ & $246 \pm 22$
\end{tabular}

* There were no statistically significant differences between the groups for any value. 


\section{Acknowledgments}

The authors are grateful to Michael J. Dunn and John R. Sedor for advice, to Ramzi Cotran and Helmut Rennke for suggesting the puromycin aminonucleoside experiment, to Nancy J. Urankar and Claudia Kesselheim for excellent technical help, and to Sara A. Cechner for typing.

This work was supported by National Institutes of Health grants DK-38544, AI-26449, and HL-37117.

\section{References}

1. Kaysen, G. A., B. D. Myers, W. G. Couser, R. Rabkin, and J. M. Felts. 1986. Biology of Disease: mechanisms and consequences of proteinuria. Lab. Invest. 31:479-498.

2. Cameron, J. S. 1984. Treatment of glomerulonephritis based on knowledge of its pathogenesis. In Nephrology, Volume II. R. R. Robinson, editor. SpringerVerlag, New York. 1445-1463.

3. Border, W. A., and R. J. Glassock. 1984. The management of the nephrotic syndrome. In Therapy of Renal Diseases and Related Disorders. W. N. Suki, and S. G. Massry, editors. Martinus Nijhoff, Boston. 195-208.

4. Ehrenreich, T., J. G. Porush, J. Churg, L. Garfinkel, S. Glabman, M. H. Goldstein, E. Grishman, and S. L. Yunis. 1976. Treatment of idiopathic membranous nephropathy. N. Engl. J. Med. 295:741-746.

5. Coggins, C. H., V. Pinn, R. R. Glassock, J. M. Blades, R. Cotran, J. Cohen, J. Churg, P. Burkholder, J. Lemann, B. Spargo, et al. 1979. A controlled study of short-term prednisone treatment in adults with membranous nephropathy. Collaborative study of the adult idiopathic nephrotic syndrome. N. Engl. J. Med. 301:1301-1306.

6. Bolton, W. K. N. O. Atuk, B. C. Sturgill, and F. B. Westervelt, Jr 1977. Therapy of the idiopathic nephrotic syndrome with alternate day steroids. Am. J. Med. 62:60-70.

7. Salant, D. J., S. Belok, M. M. Stilmant, C. A. B. Darby, and W. G. Couser. 1979. Determinants of glomerular localization of subepithelial immune deposits: effect of altered antigen to antibody ratio, steroids, vasoactive amine antagonists, and aminonucleoside of puromycin on passive Heymann nephritis in rats. Lab. Invest. 41:89-99.

8. Pusey, C. D., and C. M. Lockwood. 1984. Plasma exchange for glomerular disease. In Nephrology, Volume II. R. R. Robinson, editor. Springer-Verlag, New York. 1474-1485.

9. Kincaid-Smith, P., and R. G. Walker. 1984. The role of phasmapheresis in the nephritic syndromes: the case for plasmapheresis. In Controversies in $\mathrm{Ne}$ phrology and Hypertension. R. G. Narins, editor. Churchill Livingstone, Inc. New York. 463-485.

10. Valdes, A. J., L. B. Senterfelt, A. D. Pollack, and F. Germuth. 1969. The effect of antigen excess on chronic immune complex nephritis. Johns Hopkins Med. J. 124:9-16.
11. Wilson, C. B., and F. J. Dixon. 1971. Quantitation of acute and chronic serum sickness in the rabbit. J. Exp. Med. 134:7s-19s.

12. Haakenstad, A. O., G. E. Striker, and M. Mannik. 1983. Removal of glomerular immune complex deposits by excess antigen in chronic mouse model of immune complex disease. Lab. Invest. 48:323-331.

13. Sugisaki, T., S. Shiwachi, S. Ito, M. Yonekura, K. Kitazawa, J. Yamamoto, J. Uchida, H. Kawasumi, K. Sato, and T. Shibata. 1983. High-dose gamma globulin therapy for membranous nephropathy, membranoproliferative glomerulonephritis and lupus nephritis. Nippon Jinzo Gakkai Shi. 25:697-703.

14. Nakazawa, M., S. N. Emancipator, and M. E. Lamm. 1986. Removal of glomerular immune complexes in passive serum sickness nephritis by treatment in vivo with proteolytic enzymes. Lab. Invest. 55:551-556.

15. Nakazawa, M., S. N. Emancipator, and M. E. Lamm. 1986. Proteolytic enzyme treatment reduces glomerular deposits and proteinuria in passive $\mathrm{Hey}$ mann nephritis. J. Exp. Med. 164:1973-1987.

16. Steffen, C., and J. Menzel. 1987. In vivo-abbau von immunkomplexen in der niere durch oral applizierte enzyme. Wien. Klin. Wochenschr. 99:525-531.

17. Rahman, M. A., S. N. Emancipator, and M. J. Dunn. 1987. Immune complex effects on glomerular eicosanoid production and renal hemodynamics. Kid. Int. 31:1317-1326.

18. Kanwar, Y. S., T. Caulin-Glaser, G. R. Gallo, and M. E. Lamm. 1986. Interaction of immune complexes with glomerular heparan sulfate-proteogly cans. Kid. Int. 30:842-851.

19. Rahman, M. A., C. H. Liu, M. J. Dunn, and S. N. Emancipator. 1988. Complement and leukocyte independent proteinuria and eicosanoid synthesis in rat membranous nephropathy. Lab. Invest. 59:477-483.

20. Abboud, H. E., S. L. Ou, J. A. Velosa, S. V. Shah, and T. P. Dousa. 1982. Dynamics of renal histamine in normal rat kidney and in nephrosis induced by aminonucleoside of puromycin. J. Clin. Invest. 69:327-336.

21. Guesdon, J.-L., T. Ternynck, and S. Avrameas. 1979. The use of avidinbiotin interaction in immunoenzymatic techniques. $J$. Histochem. Cytochem 27:1131-1139.

22. Kunimitsu, D. K., and K. T. Yasunobu. 1970. Chymopapain B. Methods Enzymol. 19:244-252.

23. Ottesen, M., and I. Svendsen. 1970. The subtilisins. Methods Enzymol. 19:199-215.

24. Ikemura, $H$., and $M$. Inouye. 1988. In vitro processing of prosubtilisin produced in Escherichia coli. J. Biol. Chem. 263:12959-12963.

25. Shapira, E., and R. Arnon. 1969. Cleavage of one specific disulfide bond in papain. J. Biol. Chem. 244:1026-1032.

26. Bradley, M., and B. Schumann. 1984. Examination of urine. In Clinical Diagnosis by Laboratory Methods. 17th edition. J. B. Henry, editor. W. B Saunders Co., Philadelphia. 381-458.

27. Johansson, B. G. 1972. Agarose gel electrophoresis. Scand. J. Clin. Lab. Invest. 29(Suppl. 126):7s-17s.

28. Laemmli, U. K. 1970. Cleavage of structural proteins during the assembly of the head of bacteriophage T4. Nature (Lond.). 227:680-685.

29. Gesualdo, L., S. Ricanati, M. O. Hassan, S. N. Emancipator, and M. E. Lamm. 1990. Enzymolysis of glomerular immune deposits in vivo with dextranase/protease ameliorates proteinuria, hematuria, and mesangial proliferation in murine experimental IgA nephropathy. J. Clin. Invest. 86:715-722. 